\title{
Occurrence of killer yeast strains in industrial and clinical yeast isolates
}

\author{
MARCELO E BAEZA*, MARIO A SANHUEZA and VÍCTOR H CIFUENTES
}

Laboratorio de Genética, Departamento de Ciencias Ecológicas, Facultad de Ciencias, Universidad de Chile. Santiago, Chile

\begin{abstract}
The secretion of proteinaceous toxins is a widespread characteristic in environmental and laboratory yeast isolates, a phenomenon called "killer system". The killer phenotype $\left(\mathrm{K}^{+}\right)$can be encoded by extrachromosomal genetic elements (EGEs) as double stranded DNA or RNA molecules (dsDNA, dsRNA) or in nuclear genes. The spectrum of action and the activity of killer toxins are influenced by temperature, salinity and $\mathrm{pH}$ of media. In the present work we determined the existence of $\mathrm{K}^{+}$in a collection of $S$. cerevisiae and $P$. anomala yeasts isolated from environmental, industrial and clinical sources. The assays were performed in strains belonging to three yeast genera used as sensitive cells and under a wide range of $\mathrm{pH}$ and temperatures. Approximately $51 \%$ of isolates tested showed toxicity against at least one sensitive yeast strain under the conditions tested. The $\mathrm{K}^{+} P$. anomala isolates showed a wide spectrum of action and two of them had toxic activity against strains of the three yeast genera assayed, including $C$. albicans strains. In all $S$. cerevisiae $\mathrm{K}^{+}$ isolates an extrachromosomal dsRNA molecule $(4.2 \mathrm{~Kb})$ was observed, contrary to $P$. anomala $\mathrm{K}^{+}$isolates, which do not possess any EGEs. The $\mathrm{K}^{+}$phenotype is produced by an exported protein factor and the kinetics of killer activity production was similar in all isolates with high activity in the log phase of growth, decaying in the stationary phase.
\end{abstract}

Key terms: killer system, mycotoxin, dsRNA.

\section{INTRODUCTION}

Many yeast synthesize and export proteins or glycoproteins with toxic effects against sensitive yeasts, a phenomenon called "killer system" (Young and Yagiu, 1978; Tipper and Bostian, 1984; Magliani et al., 1997; Marquina et al, 2002). Similar to that described in bacteriocins, it has been proposed that in natural habitats the production of these toxins confer to killer $\left(\mathrm{K}^{+}\right)$yeast an advantage over sensitive microorganisms in the competition for nutrients (Lenski and Riley, 2002). The killer system was described for the first time in S. cerevisiae (Bevan and Makower, 1963) and soon after in many other yeast genera, such as Candida, Cryptococcus, Debaryomyces, Hanseniaspora, Hansenula, Kluyveromyces, Ustilago, Pichia, etc.
(Schmitt and Breinig, 2002). The killer activity of yeast is detectable only when it is assayed against proper yeast as sensitive, and is dependent on several factors, such as $\mathrm{pH}$, salinity and temperature. Generally the killer toxins described are active at $\mathrm{pH}$ values from 3 to 5.5 (Golubev and Shabalin, 1994; Marquina et al., 2002). The genetic elements that encode for a killer phenotype may be double stranded RNA molecules (dsRNA) encapsulated in viruslike particles (VLPs), linear double stranded DNA plasmids (dsDNA) or nuclear genes (Schmitt and Breinig, 2002). The killer system of $S$. cerevisiae is the best studied model, corresponding to a genetically complex phenomenon because it depends both on cytoplasmic factors and approximately forty cellular genes (Wickner, 1976; Cartwright, 1992; van

\footnotetext{
* Corresponding Author: Mailing address: Laboratorio de Genética, Depto. de Ciencias Ecológicas, Facultad de Ciencias, Universidad de Chile. Las Palmeras 3425, Casilla 653, Santiago, Chile. Telephone: 9787256. Fax: 2729378. E-mail: mbaeza@uchile.cl
} 
Vuuren, 1992; Vermut, 1994; Yasuyuki, 1995). The $\mathrm{K}^{+}$strains of $S$. cerevisiae have been classified in 3 groups (K1, K2 and K8) according to their toxin properties, mechanism of action, crossed immunity and genetic determinants (Magliani et al., 1997; Marquina et al., 2002). Two classes of dsRNA with different molecular sizes and functions are responsible for the killer phenotype in this yeast: L-dsRNA $(4.6 \mathrm{~kb})$ that encodes for a RNA polymerase and for capside proteins of VLPs; and M-dsRNA $(1.6-1.8 \mathrm{~kb})$ that encode for the toxin and confer immunity (Tipper and Bostian, 1984). The main mechanisms of action described for killer toxins are the formation of ionic channels in the cytoplasmic membrane and the inhibition of DNA synthesis (Magliani et al., 1997).

Investigations of killer systems have contributed important advances in basic and general aspects of eukaryotic cell biology, host-virus interaction and yeast virology. Furthermore, detailed analysis of toxin synthesis and structure has reinforced knowledge about the mechanisms of preprotein processing and postraduccional modification in the eukaryotic secretion pathway. On the other hand, the possibility of finding killer toxins active against pathogens of medical importance is attractive for the treatment of fungal infections (Conti et al., 1998). An example is the killer system described in Pichia anomala, which shows toxic activity against a wide variety of nonrelated microorganisms, such as hyphomycetes and bacteria, including important opportunist pathogens, such as Candida albicans (Polonelli et al., 1986; Polonelli et al., 1989; Turchetti and Buzzini, 2003). In the biotechnological area, the use of killer strains to eliminate undesirable microorganisms in industrial fermentations or in food preservation has been suggested (Sulo and Michalcakova, 1992; Sulo et al., 1992; Lowes et al., 2000).

In the present work, we analyzed the existence of $\mathrm{K}^{+}$phenotype in a collection of $S$. cerevisiae strains obtained from industrial wine fermentation, and $P$. anomala strains isolated from environmental and clinical sources. Determinations of $\mathrm{K}^{+}$phenotype were performed using strains of the Saccharomyces, Rhodotorula and Candida genera as sensitive cells. The $\mathrm{K}^{+}$strains obtained were characterized in relation to the optimal temperature and $\mathrm{pH}$ for activity, and the kinetics of the production of killer activity. At a molecular level, the $\mathrm{K}^{+}$yeasts were analyzed in relation to the presence and chemical nature of extrachromosomal genetic elements.

\section{MATERIALS AND METHODS}

Yeast strains: Yeast isolates obtained from Chilean wine-producing areas (Martínez et al., 2004) were named V1, V2, V3, etc. The $P$. anomala strains isolated from environmental (A1, A2, A3, etc.) and clinical (P1, P2, P3, etc.) sources were described previously (Reyes et al., 2004). The strains AH22 (ATCC 38626) of $S$. cerevisiae, 1001 (ATCC 64385) and 5314 of C. albicans, and Rhodotorula sloffiae (CBS 7095) were used as killer-sensitive cells.

Culture media: Yeast cells were grown in YM medium containing $1 \%$ glucose, $0.3 \%$ malt extract, $0.3 \%$ yeast extract and $0.5 \%$ peptone. YM-MB (YM containing $0.003 \%$ methylene blue and $1.5 \%$ agar) was used in assays for the killer phenotype.

Assay for mycocinogenic activity: Determinations were performed according to the method described previously (Salek et al., 1990). Sensitive lawns were made by mixing $200 \mu \mathrm{l}$ of fresh culture of the sensitive strain with $20 \mathrm{ml}$ of YM-MB (40 ${ }^{\circ} \mathrm{C}$ ), buffered with citrate-phosphate to obtain $\mathrm{pH}$ values ranging from 4.2 to 5.8 at intervals of 0.4 units, and poured onto Petri plates. The yeast isolates were seeded onto the sensitive lawns and the plates were incubated at 22,30 or $37^{\circ} \mathrm{C}$ for 3 to 7 days. Positive killer activity was observed by a clear zone, surrounded by a blue precipitated halo, indicative of cellular death.

Determination of killer activity by the well test method: A volume of $100 \mu \mathrm{l}$ of sample was inoculated into wells $(10-\mathrm{mm}$ diameter) cut into sensitive cell lawns and the diameters of the death zones were measured after incubation for 3 to 7 days at 
22 or $30{ }^{\circ} \mathrm{C}$. Killer toxin activity was calculated according to the formula $\mathrm{D}=5$ $\log \mathrm{A} \times 10$, where $\mathrm{D}$ is the diameter of death zone in $\mathrm{mm}$, and $\mathrm{A}$ the activity in $\mathrm{UA} / \mathrm{ml}$ (Schmitt and Tipper, 1990; Gulbiniene et al., 2004).

Determination of viable cells: Serial dilutions of culture samples were made and aliquots were seeded onto YM agar plate. After incubation at $22{ }^{\circ} \mathrm{C}$ for 3-5 days, the colony forming units were determined.

Extraction of total nucleic acids: The nucleic acids were purified from protoplasts of yeasts. Cells were collected by centrifugation at $10,000 \mathrm{~g}$ for $10 \mathrm{~min}$, resuspended in $5 \mathrm{ml}$ of $0.9 \mathrm{M}$ sorbitol, 0.1 M EDTA, $100 \mu \mathrm{g} / \mathrm{ml}$ zymoliase 100T and incubated for $25 \mathrm{~min}$ at $37^{\circ} \mathrm{C}$. After centrifugation at $4,000 \mathrm{~g}$ for $5 \mathrm{~min}$, the cellular pellet was resuspended in $5 \mathrm{ml}$ of $50 \mathrm{mM}$ Tris- $\mathrm{HCl}, 20 \mathrm{mM}$ EDTA, $1 \%$ SDS and incubated at $65{ }^{\circ} \mathrm{C}$ for $15 \mathrm{~min}$. Then, $50 \mu \mathrm{l}$ of proteinase $\mathrm{K}(20 \mathrm{mg} / \mathrm{ml})$ was added, incubated at $55{ }^{\circ} \mathrm{C}$ for $1 \mathrm{~h}$ and after the addition of $2 \mathrm{ml}$ of cold $5 \mathrm{M}$ potassium acetate, was incubated on ice for $10 \mathrm{~min}$. One volume of saturated phenol pH 8.0 was added and both phases were mixed gently. The aqueous phase was recovered and washed twice with 1 volume of phenol:chloroform:isoamylic alcohol (25:24:21) and once with chloroform:isoamylic alcohol (24:1). The nucleic acids were precipitated with 2 volumes of ethanol at $-20^{\circ} \mathrm{C}$.

Enzymatic treatments: Samples were treated with DNaseI, Nuclease S1, and RNaseH according to Sambroook et al. (1989), and Muthukrishnan and Shatkin (1975). Digestions with RNAseA were made in $\mathrm{SSC}$ buffer $(0.3 \mathrm{M} \mathrm{NaCl}, 0.03 \mathrm{M}$ sodium citrate, $\mathrm{pH} 7.0)$ at high (2 x SSC) and low (0.01 x SSC) ionic strength (Pryor and Boelen, 1987; Castillo and Cifuentes, 1994 ).

Gel electrophoresis: The samples were separated electrophoretically in $1 \%$ agarose gels in TAE buffer containing ethidium bromide $(0.5 \mu \mathrm{g} / \mathrm{ml})$ and photographed under transilluminated UV light. The size of the bands was determined using the 1D Image Analysis Software version 2.0.1 (Kodak Scientific Image System) using as standard the $\lambda$-HindIII DNA marker
(Fermentas), and corrected according to mobility difference between dsDNA and dsRNA molecules (Livshits et al., 1990).

PCR amplification: The primer pairs ITS 1 (5'-TCCGTAGGTGAACCTGCG-3') and ITS4 (5'-TCCTCCGCTTATTGATAT GC-3') were used to amplify the $5.8 \mathrm{~S}$ rDNA and the adjacent ITS1 and ITS2 regions (Fujita and Hashimoto, 2001). The PCR reaction was performed in $25 \mu \mathrm{l}$ final volume as follows: $10 \mathrm{ng}$ of DNA, $2.5 \mu \mathrm{l}$ of 10X PCR buffer, $0.5 \mu \mathrm{l}$ of dNTP's mixture (10 $\mathrm{mM}$ of each), $2 \mu \mathrm{l}$ of ITS1 and ITS2 primer mix ( $25 \mu \mathrm{M}$ of each), $1 \mu \mathrm{l}$ of $\mathrm{MgCl}_{2}$ $(50 \mathrm{mM})$ and $0.2 \mu \mathrm{l}(1 \mathrm{U})$ of $\mathrm{Taq}$ polymerase (New England Biolabs). The final volume was adjusted with nuclease free water. Amplification was performed in a GeneAmp PCR system 2700 thermal cycler (Applied Biosystem) as follows: initial denaturation at $94{ }^{\circ} \mathrm{C}$ for $5 \mathrm{~min} ; 30$ cycles of denaturation at $94{ }^{\circ} \mathrm{C}$ for $30 \mathrm{~s}$, annealing at $55^{\circ} \mathrm{C}$ for $30 \mathrm{~s}$ and synthesis at $72{ }^{\circ} \mathrm{C}$ for $1 \mathrm{~min}$; and a final extension step at $72{ }^{\circ} \mathrm{C}$ for $10 \mathrm{~min}$. Control reactions without DNA were carried out simultaneously. The amplified products were separated electrophoretically in $1 \%$ agarose gels in TAE buffer containing ethidium bromide $(0.5 \mu \mathrm{g} / \mathrm{ml})$ and photographed under transilluminated UV light. The amplicons were purified from the agarose gels by an alternative to the glassmilk method (Boyle and Lew, 1995).

Automated DNA sequencing and data analysis: Nucleotide sequencing was performed using the DNA Sequencing Kit Dynamic Termination Cycle (Amersham Biosciences Limited), according to the manufacturer's instructions, and the Genetic analyzer 3100 Avant automatic sequencer (Applied Biosystem). The sequence data was analyzed using the Vector NTI 10.1 (Invitrogen Corporation).

Toxin crude extract preparations: Cell culture samples were centrifuged at 7,000 g for $5 \mathrm{~min}$ at $4{ }^{\circ} \mathrm{C}$. The supernatant was filtered through sterile $0.22-\mu \mathrm{m}$ pore size polivinyliden fluoride membrane (Millipore).

Protein precipitation: A volume of ethanol was added to the cell-free supernatant to achieve a final concentration of $70 \% \mathrm{v} / \mathrm{v}$, incubated at $4^{\circ} \mathrm{C}$ for $1 \mathrm{~h}$ and 
centrifuged at $16,000 \mathrm{~g}$ for $40 \mathrm{~min}$. The pellet was dried and resuspended in $1-2 \mathrm{ml}$ phosphate/citrate buffer $\mathrm{pH}$ 4.6. Samples were maintained at $-20{ }^{\circ} \mathrm{C}$.

\section{RESULTS}

The existence of a killer phenotype was investigated in $16 P$. anomala strains of environmental and clinical origin (Reyes et al., 2004), and in 35 yeast isolates obtained from industrial wine fermentations. For the identification of industrial yeast isolates, a region spanning the internal transcribed spacer ITS1 and ITS2 (including 5.8S rDNA gene) was amplified using ITS1 and ITS4 primers (Fujita and Hashimoto, 2001). The PCR products were separated by agarose gel electrophoresis, the amplicons obtained were purified from the gel and both DNA strands were sequenced. From the analysis and comparison of sequences against the data base, all yeast isolates were identified as $S$. cerevisiae with an average identity of $96 \%$.

\section{Determination of killer activity at different temperatures and $\mathrm{pH}$ values}

A preliminary screening of $\mathrm{K}^{+}$yeast was performed on $S$. cerevisiae $\mathrm{AH} 22$ lawns (commonly used as killer-sensitive strain) buffered at $\mathrm{pH} 4.6$, value in which are active the most killer yeast reported. Yeast isolates were seeded onto these lawns and incubated at 22,30 and $37{ }^{\circ} \mathrm{C}$. The $\mathrm{K}^{+}$strains were identified by the presence of a death halo (precipitate of methylen blue) of the sensitive cells, as is shown in figure 1. All $\mathrm{K}^{+}$yeasts showed more activity at 22 (fig 1B) rather than $30{ }^{\circ} \mathrm{C}$ (fig $1 \mathrm{~A}$ ), according to the diameter of the death zone, and no $\mathrm{K}^{+}$ strains were observed at $37^{\circ} \mathrm{C}$ (not shown). Similar results were obtained using $R$. sloffiae as sensitive cells. When the assays were performed using $C$. albicans lawns, $\mathrm{K}^{+}$ yeast were observed only on $C$. albicans A5314 lawns at $30{ }^{\circ} \mathrm{C}$ (not shown). Therefore, the determinations of the optimal $\mathrm{pH}$ for killer activity were performed at 22 ${ }^{\circ} \mathrm{C}$ for $S$. cerevisiae and $R$. sloffiae, and at 30 ${ }^{\circ} \mathrm{C}$ for $C$. albicans lawns. The $\mathrm{pH}$ values of the cell lawns were adjusted from 4.2 to 5.8 with phosphate/citrate buffer. The yeasts analyzed were streaked onto the cell lawns and the plates were incubated for 3-7 days. The results obtained for $\mathrm{K}^{+}$yeast isolates are summarized in table I. Fifteen yeast isolates showed $\mathrm{K}^{+}$phenotype on $S$. cerevisiae $\mathrm{AH} 22$ lawns, corresponding to $12 \mathrm{~S}$. cerevisiae and $3 P$. anomala isolates, in the $\mathrm{pH}$ range of 4.2 to 5.4. When the assay was performed on $R$. sloffiae lawns, 16 yeast isolates showed
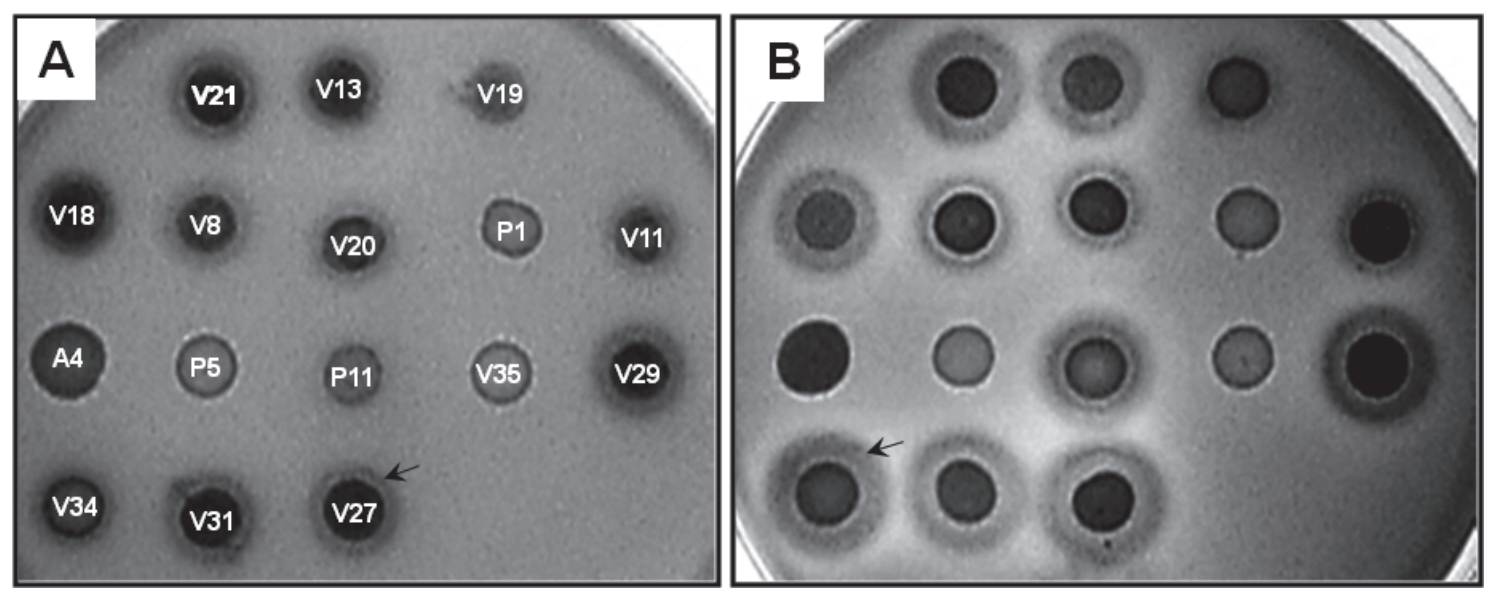

Figure 1: Agar plate assay for killer activity: A cells lawn of S. cerevisiae AH22 was made in YM$\mathrm{MB}$ agar ( $\mathrm{pH} 4.6)$ and $10 \mu \mathrm{l}$ of yeast cultures were deposited onto this lawn. The plates were incubated at 30 (A) and $22{ }^{\circ} \mathrm{C}(\mathrm{B})$. The number position represents the same strain in each panel. Arrow indicates the death zone (precipitate of methylen blue). 
TABLE I

Determination of killer activity of different yeast isolates

\begin{tabular}{lllllll}
\hline Sensitive Strain & \multirow{2}{*}{$\mathrm{K}^{+}$strain } & \multicolumn{5}{c}{$\mathrm{pH}$} \\
\cline { 3 - 7 } & & 4.2 & 4.6 & 5.0 & 5.4 & 5.8
\end{tabular}

S. cerevisiae $\mathrm{AH} 22$

R. sloffiae

$\begin{array}{ccccc}\text { A5 } & +++ & - & - & - \\ \text { A6 } & - & + & - & - \\ \text { P11 } & \pm & ++ & +++ & + \\ \text { V8 } & +++ & ++ & ++ & - \\ \text { V11 } & ++ & +++ & ++ & - \\ \text { V13 } & - & ++++ & ++++ & + \\ \text { V18 } & ++++ & ++++ & ++++ & + \\ \text { V19 } & ++ & ++++ & ++ & \pm \\ \text { V20 } & - & +++ & ++ & - \\ \text { V21 } & +++ & ++++ & ++++ & + \\ \text { V23 } & - & + & - & - \\ \text { V27 } & + & ++ & + & - \\ \text { V29 } & ++ & ++++ & +++ & + \\ \text { V30 } & +++ & ++++ & +++ & + \\ \text { V34 } & \pm & ++ & ++ & +\end{array}$

C. albicans 5314*

$\begin{array}{llllll}\text { A1 } & \pm & + & ++ & + & \pm \\ \text { A2 } & \pm & + & ++ & + & \pm \\ \text { A4 } & - & + & ++ & + & \pm \\ \text { A5 } & \pm & + & ++ & + & \pm \\ \text { A6 } & \pm & + & ++ & + & - \\ \text { P1 } & & \pm & ++ & + & \pm \\ \text { P2 } & \pm & + & ++ & + & \pm \\ \text { P5 } & - & + & ++ & + & - \\ \text { P7 } & - & - & + & + & \pm \\ \text { P11 } & \pm & + & ++ & + & \pm \\ \text { P12 } & \pm & + & ++ & + & - \\ \text { P16 } & - & - & + & + & - \\ \text { P18 } & \pm & + & ++ & + & \pm \\ \text { P21 } & \pm & + & ++ & + & \pm \\ \text { V13 } & \pm & + & ++ & - & - \\ \text { V34 } & \pm & + & ++ & + & \pm\end{array}$

$\begin{array}{ccc}\text { A1 } & ++ & ++ \\ \text { A4 } & - & ++ \\ \text { A5 } & ++ & ++ \\ \text { P5 } & ++ & ++ \\ \text { P11 } & ++ & - \\ \text { P16 } & ++ & ++\end{array}$

The plate killer assay was performed as described in Materials and Methods (see fig. 1). *, results obtained after incubation at $30{ }^{\circ} \mathrm{C}$. - , no sensitivity; + to ++++ , low to extensive sensitivity; \pm , uncertain sensitivity. 
killer activity at $\mathrm{pH}$ values of between 4.2 and $5.8,14$ of them corresponding to $P$. anomala isolates. Seven strains showed toxicity against $C$. albicans 5314 in $\mathrm{pH}$ range from 4.2 and 4.6 , all belonging to $P$. anomala isolates, while no $\mathrm{K}^{+}$yeast on $C$. albicans 1001 lawns was observed at 22 and $30{ }^{\circ} \mathrm{C}$ in the $\mathrm{pH}$ range from 4.2 to 5.8 . According to the spectrum of action, the $\mathrm{K}^{+}$ isolates can be divided into 5 groups: Group1, active only against $S$. cerevisiae AH22 (V8, V11, V18, V19, V20, V21, V23, V27, V29, V30); Group 2, killer activity only against $R$. sloffiae (A2, P1, P2, P7, P18, P21); Group 3, killer activity against $S$. cerevisiae $\mathrm{AH} 22$ and $R$. sloffiae (A6, V13, V34); Group 4, killer activity against $R$. sloffiae and C. albicans 5314 (A1, A4, P5, P12, P16); and Group 5, represented by P11 and A5 isolates of $P$. anomala that display killer activity against all three $S$. cerevisiae AH22, R. sloffiae and C. albicans 5314 strains.

\section{Extraction and electrophoresis of nucleic acids}

To determine the existence of exctrachromosomal genetic elements (EGEs) in $\mathrm{K}^{+}$yeast, the total nucleic acids were purified from a culture of each isolate and analyzed by agarose gel electrophoresis. None of the $\mathrm{K}^{+}$isolates of $P$. anomala showed the presence of any extrachromosomal band of nucleic acids. The $S$. cerevisiae $\mathrm{K}^{+}$isolates showed the presence of one extrachromosomal band of nucleic acids of about $4.2 \mathrm{~kb}$, with the exception of the isolate V34. For the determination of the chemical nature of these EGEs, the samples were treated with different DNases and RNases, and resolved in agarose gels. As is shown in figure $2 \mathrm{~A}$ and $2 \mathrm{~B}$, these molecules were not digested by treatment with $\mathrm{RNaseH}$ and DNaseI, indicating that they were not hybrid DNA/ RNA or DNA molecules, respectively. When the samples were treated with RNaseA at different ionic strength, they were degraded only under low ionic strength conditions (figure 2C, 2D), indicative that these extrachromosomal elements are molecules of dsRNA.

\section{Kinetics of the killer activity production}

To determine if toxic activity of $\mathrm{K}^{+}$yeast isolates is produced by an exported factor, aliquots of $100 \mu \mathrm{l}$ of cell-free crude extract obtained from yeast cultures was seeded

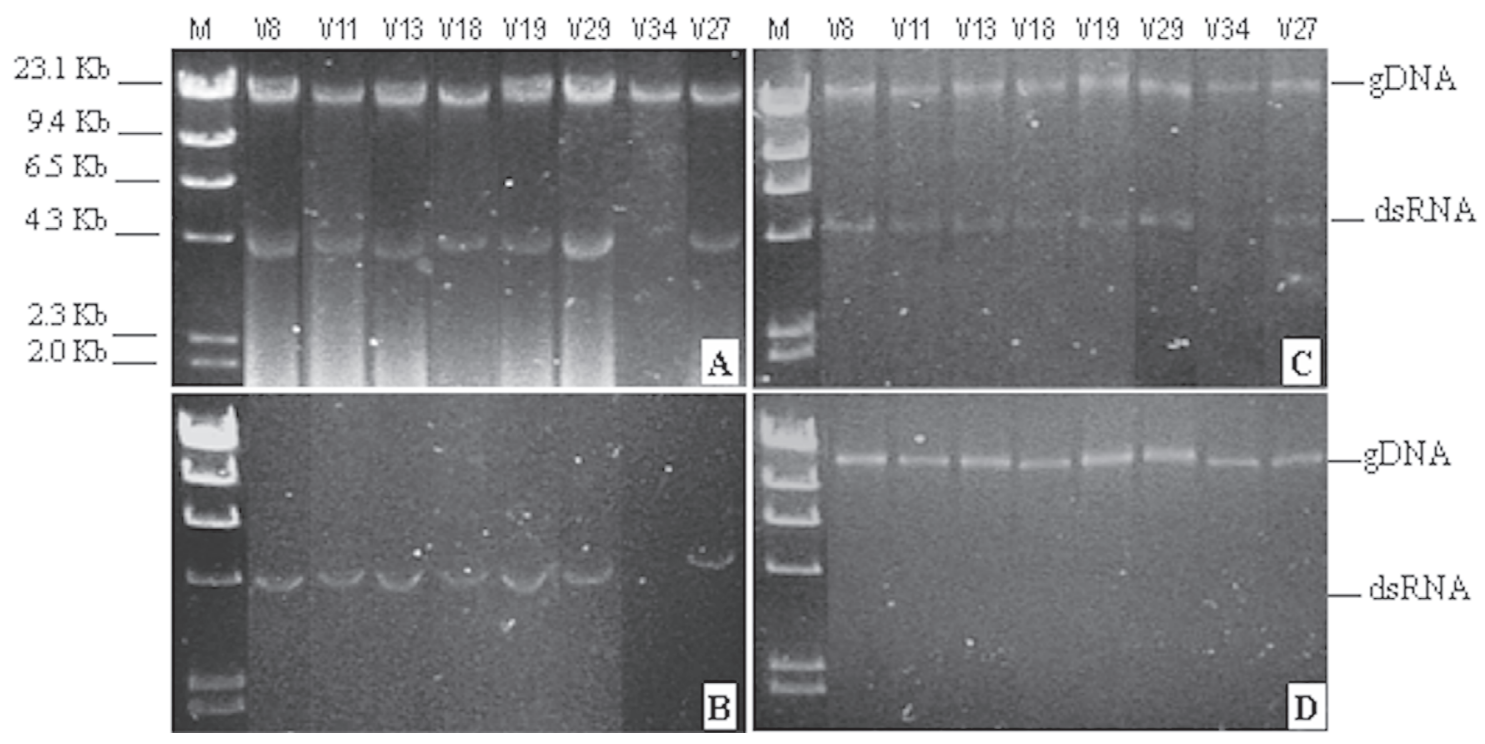

Figure 2: Agarose gel electrophoresis of total nucleic acids isolated from $\mathrm{K}^{+}$yeasts: The samples were treated with RNaseH (A), DNaseI (B), and with RNaseA at high (C) and low (D) ionic strength. M, $\lambda$-HindIII DNA marker. gDNA, genomic DNA. dsRNA, double stranded RNA. 
into wells made in lawns of $S$. cerevisiae AH22. An example of these assays is shown in figure 3 , where a death halo surrounding the wells seeded with extract from V20, V21 and V34 yeast cultures can be observed, contrary to $S$. cerevisiae AH22 crude extract. These results strongly suggest that an exported factor is responsible for the toxic activity in $\mathrm{K}^{+}$ isolates. The kinetics of killer activity production was determined along the growth curve of six $\mathrm{K}^{+}$yeast isolates grown in YM media at $\mathrm{pH} 4.6$ and $22{ }^{\circ} \mathrm{C}$. As is shown in figure 4 , a similar kinetics was observed in all yeast cultures analyzed with an increase in killer activity in the log phase, followed by a decay of activity parallel to the decrease of cell viability (death phase). The exception was the V18 isolate which showed killer activity over a long period of time $(160 \mathrm{~h})$ even when the culture was in late stationary phase. Two of $S$. cerevisiae and $P$. anomala $\mathrm{K}^{+}$isolates were selected and their kinetics of activity production were determined, this once with extracellular proteins obtained by ethanol precipitation. The activity of the protein extract was determined on $S$. cerevisiae
AH22 and $C$. albicans 5314 lawns for $S$. cerevisiae and $P$. anomala $\mathrm{K}^{+}$isolates, respectively. The kinetics of killer activity production by cultures of $S$. cerevisiae $\mathrm{K}^{+}$ showed an increase in the log phase followed by a decay in the stationary phase (fig $5 \mathrm{~A}$ ). The toxic activity against $C$. albicans of P11 isolate showed an increment in the log phase of growth, decaying at the end of this phase. The A5 isolate showed an increment of activity in the log phase, which was maintained even in the stationary phase (fig $5 \mathrm{~B}$ ).

\section{DISCUSSION}

To evaluate the existence of a killer phenotype in a collection of $S$. cerevisiae and $P$. anomala isolates we used strains of three yeast genera as sensitive cells: $S$. cerevisiae AH22 ("universal" sensible strain); R. sloffiae (environmental isolate); and $C$. albicans 1001 and 5314 strains, with potential clinical interest. The assays were performed in a wide range of temperature and $\mathrm{pH}$, parameters with a strong influence in the determination of killer phenotype.

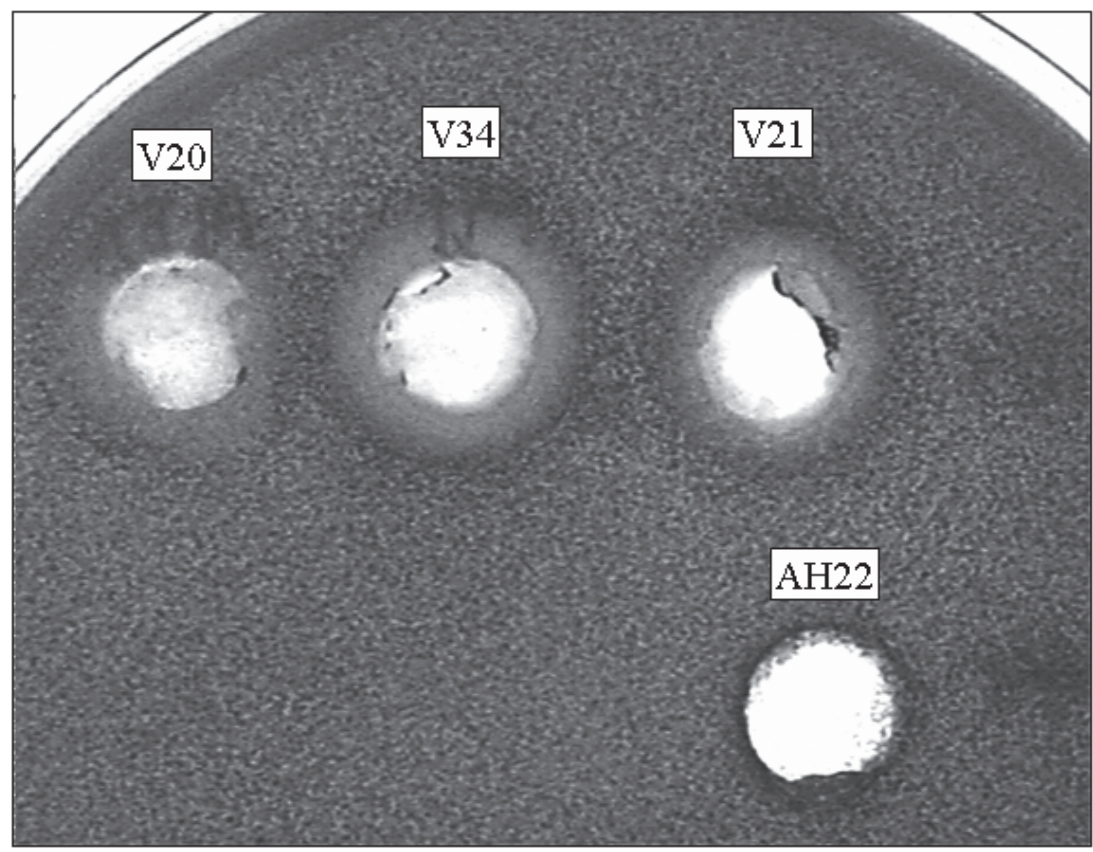

Figure 3: Well test assay of supernatant of $\mathrm{K}^{+}$yeast cultures: A $100 \mu \mathrm{l}$ sample of culture filtrate was added to wells (10-mm diameter) made in a lawn of $S$. cerevisiae AH22. 

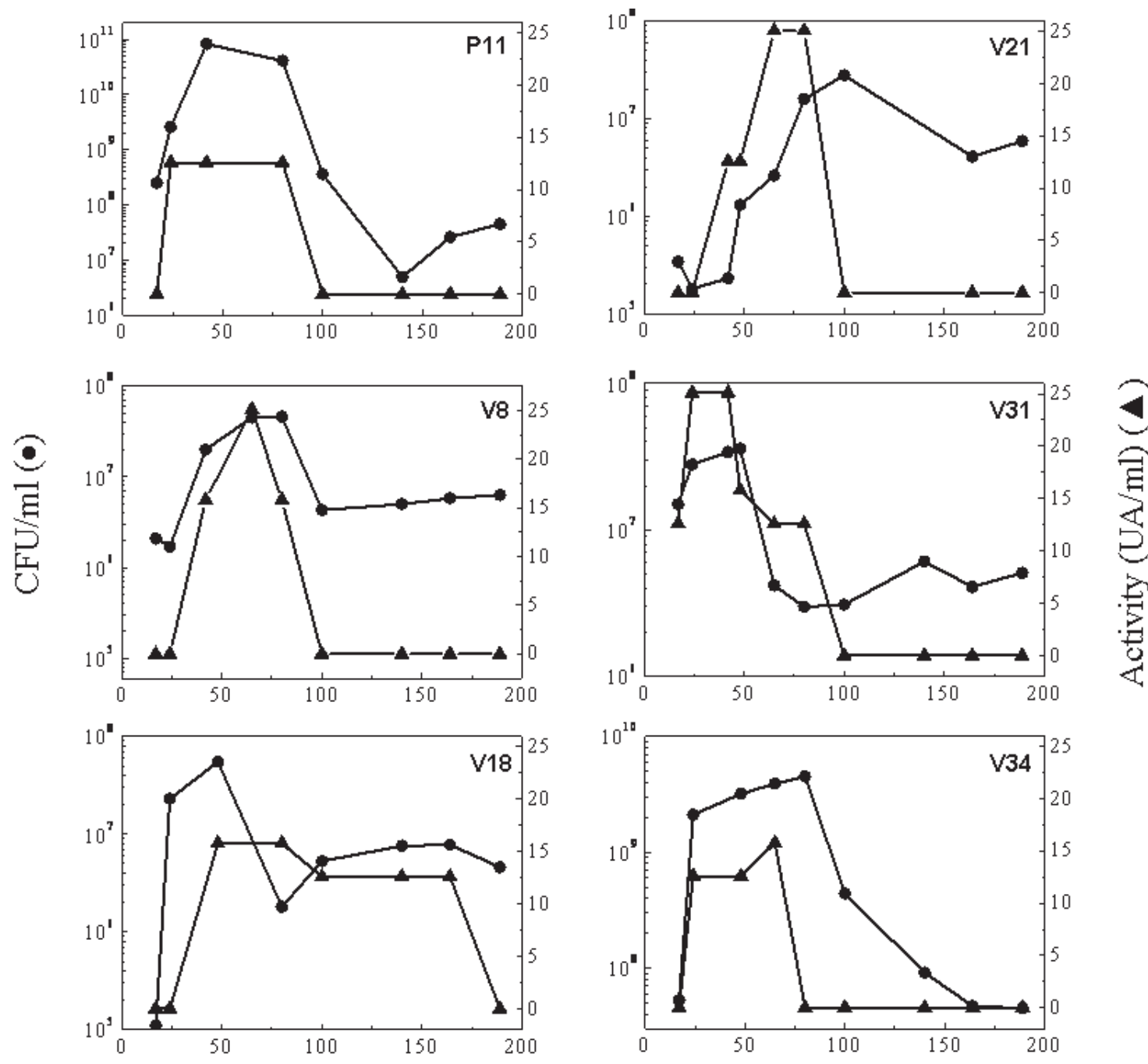

Ti m e, h.

Figure 4: Kinetics of toxin production of $\mathrm{K}^{+}$yeast isolates: Yeasts were grown in $\mathrm{YM}$ broth at $\mathrm{pH}$ 4.6 and $22{ }^{\circ} \mathrm{C}$ with constant shaking. A $100 \mu \mathrm{l}$ sample of culture filtrate was added to wells (10-mm diameter) in pour plates of $S$. cerevisiae AH22 lawn.

All $\mathrm{K}^{+}$isolates showed activity at $\mathrm{pH}$ values below 5.4, which agrees with most of the killer yeasts described in the literature. A relation between the sensitive strain and optimal $\mathrm{pH}$ for killer activity was found. An example is the isolate A5 of $P$. anomala whose optimal $\mathrm{pH}$ was 4.2 on $S$. cerevisiae, 5.0 on $R$. sloffiae and $4.2-4.6$ on $C$. albicans. Differences in the spectrum of activity among $S$. cerevisiae isolated from wine fermentation suggest the existence of different strains that can be grouped in: i) active only against $S$. cerevisiae AH22 (10 isolates); ii) active against $S$. cerevisiae AH22 and $R$. sloffiae (2 isolates); and iii) no killer strains. These results would complement molecular methods used for the differentiation of yeast strains of the same or different origins (Martínez et al., 2004). Likewise, the clinical isolates of $P$. anomala can be grouped by their activity against: i) $R$. sloffiae (6 isolates); ii) $S$. cerevisiae $\mathrm{AH} 22$ and $R$. sloffiae (1 isolate); iii) $R$. sloffiae and C. albicans (5 islotates); and iv) $S$. cerevisiae, $R$. sloffiae and $C$. albicans ( 2 isolates). The strains that have a 


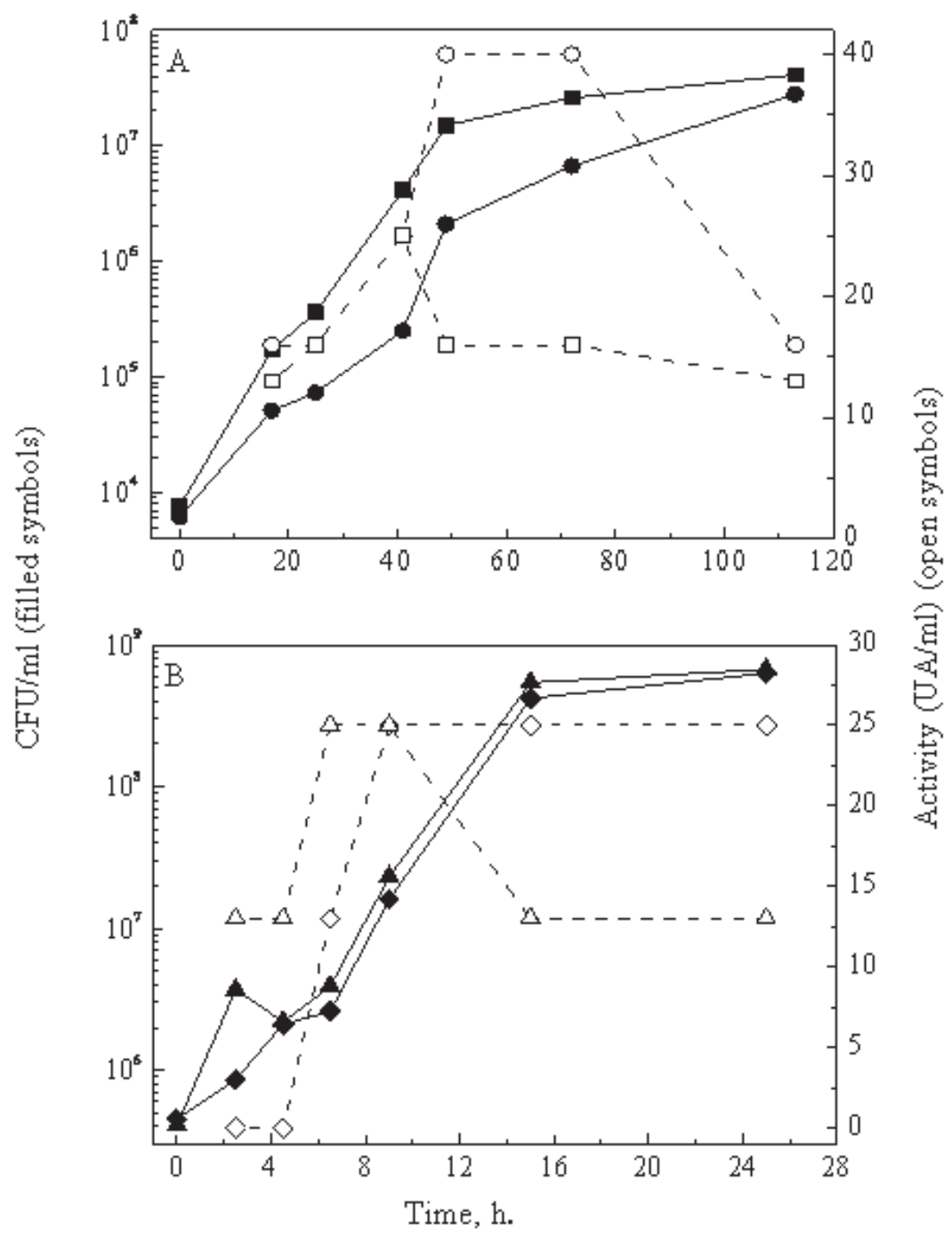

Figure 5: Kinetics of toxin production of $\mathrm{K}^{+}$S. cerevisiae (A) and P. anomala (B) isolates: Yeasts were grown in $\mathrm{YM}$ broth at $\mathrm{pH}$ 4.6. In each point the protein from the cell-free supernatant was obtained by ethanol precipitation as described in materials and methods. Killer activity of samples was determined by the well test method on S. cerevisiae AH22 (A) and C. albicans 5314 (B) lawns. V18, circles; V21, squares; P11, triangles; A5, rhombs.

wide spectrum of action are interesting because they display toxic activity against yeasts of industrial and/or clinical interest. At a molecular level, all $\mathrm{K}^{+}$isolates of $P$. anomala and the $S$. cerevisiae V34 do not have any EGEs, suggesting that the phenotype is encoded in the genome of the cells. In the other $\mathrm{K}^{+}$isolates of $S$. cerevisiae, a dsRNA molecule of about 4.2 $\mathrm{kb}$ was observed and according to its molecular size it could correspond to the helper virus (L-dsRNA) of the killer system of $S$. cerevisiae. However in $\mathrm{K}^{+} S$. cerevisiae strains the killer toxin is encoded by the satellite virus (M-dsRNA) with a molecular size of between 1.6 to $1.8 \mathrm{~Kb}$. This does not agree with the presence only of the helper virus in all $\mathrm{K}^{+}$isolates described in this work, suggesting that the toxin production is encoded in the genome. Similar results were obtained by other authors in yeast isolated from fruits and berry wine yeast populations (Gulbiniene et al., 2004). 


\section{ACKNOWLEDGEMENTS}

We thank Claudio Martinez for supplying the wine yeast isolates. This work was supported by grants I 04/08-2 Universidad de Chile and Fondecyt 1040450.

\section{REFERENCES}

BEVAN E, MAKOWER M (1963) The physiological basis of the killer-character in yeast. In Proc Xlth Int Congr Genetics, Pergamon Press, The Netherlands. Volume I, page 203

BOYLE J, LEW A (1995) An inexpensive alternative to glassmilk for DNA purification. TIG 11:8

CARTWRIGHT C, ZHU Y, TIPPER D (1992) Efficient secretion in yeast based on fragments from K1 killer preprotoxin. Yeast 8: 261-272

CASTILlO A, CIFUENTES V (1994) Presence of double stranded RNA and virus-like particles in Phaffia rhodozyma. Current Genetics 26: 364-368

CONTI S, MAGLIANI W, GERLONI M, SALATI A, DIECI E, ARSENI S, FISICAZO P, POLONELLI L (1998) XIX. A transphyletic anti-infectious control strategy based on the killer phenomenon. FEMS Immunol Med Microbiol 22: 151-161

FUJITA S, HASHIMOTO T (2001) Multiplex PCR using internal transcribed spacer 1 and 2 regions for rapid detection and identification of yeast strains. J Clin Microbiol 39: 3617-3622

GOLUBEV W, SHABALIN Y (1994) Mycocin production by the yeast Cryptococcus humicola. FEMS Microbiol Lett 119: 105-110

GULBINIENE G, KONDRATIENE L, JOKANTAITE T, SERVIENE, MELVYDAS E, PETKUNIENE G (2004) Occurrence of killer yeast strains in fruit and berry wine yeast populations. Food Technol Biotechnol 42: 159-163

KURTZMAN C, FELL J (2000) The Yeasts, a taxonomic study, Amsterdam, 4ed

LENSKI R, RILEY M (2002) Chemical warfare from an ecological perspective. Proc Natl Acad Sci 99: 556-558

LIVSHITS M, AMOSOVA O, LYUBCHENKO Y (1990) Flexibility difference between double-stranded RNA and DNA as revealed by gel electrophoresis. J Biomol Struct Dyn 7: 1237-1249

LOWES K, SHEARMAN C, PAYNE J, MACKENZIE D, ARCHER D, MERRY R, GASSON M (2000) Prevention of yeast spoilage in feed and food by the yeast mycocin HMK. Appl Environ Microbiol 66: 1066-1076

MAGLIANI W, CONTI S, GERLONI M, BERTOLOTTI D, POLONELLI L (1997) Yeast killer systems. Clin Microbiol Rev 10: 369-400

MARQUINA D, SANTOS A, PEINADO JM (2002) Biology of killer yeasts. Int Microbiol 5: 65-71

MARTÍNEZ C, GAC S, LAVIN A, GANGA M (2004) Genomic characterization of Saccharomyces cerevisiae strains isolated from wine-producing areas in South America. J Appl Microbiol 96: 1161-1168

MUTHUKRISHNAN S, SHATKIN A (1975) Reovirus genome RNA segments: resistance to $\mathrm{S}-1$ nuclease. Virology 64: 96-105

POLONELLI L, LORENZINI R, DE BERNARDINIS F, MORACE G (1986) Potential therapeutic effect of yeast killer toxin. Mycopathologia 96: 103-107

POLONELLI L, MANZARA S, CONTI S, DETTORI G, MORACE G, CHEZZI C (1989) Serological study of yeast killer toxins by monoclonal antibodies. Mycopathologia 108: 211-215

PRYOR A, BOELEN M (1987) A double-stranded RNA mycovirus from the maize rust Puccinia sorghi. Can J Bot 65: 2380-2383

REYES E, BARAHONA S, FISCHMAN O, NIKLITSCHEK $M$, BAEZA $M$, CIFUENTES V (2004). Genetic polymorphism of clinical and environmental strains of Pichia anomala. Biol Res 37: 747-57

SALEK A, SCHNETTLER R, ZIMMERMANN U (1990) Transmission of killer activity into laboratory and industrial strains of Saccharomyces cerevisiae by electroinjection FEMS Microbiol Lett 70: 67-72

SAMBROOK J, FRITSCH E, MANIATIS T (1989) Molecular cloning: a laboratory manual. Cold Spring Harbor Laboratory Press, Cold Spring Harbor, NY

SCHMITT M, BREINIG F (2002) The viral killer system in yeast: from molecular biology to application. FEMS Microbiol Rev. 26: 257-76

SCHMITT M, TIPPER D (1990). K28, a unique doublestranded RNA killer virus of Saccharomyces cerevisiae. Mol Cell Biol 10: 4807-4815

SULO P, MICHALCAKOVA S, REISER V (1992) Construction and properties of K1 type killer wine yeasts. Biotechnol Lett 14: 55-60

SULO P, MICHALCAKOVA S (1992) The K3 type killer strains of genus Saccharomyces for wine production. Folia Microbiol 37: 289-294

TIPPER D, BOSTIAN K (1984) Double-stranded ribonucleic acid killer systems in yeasts. Microbiol Rev 48: 125-156

TURCHETTI B, BUZZINI P (2003) Exploration of natural killer yeast biodiversity as a possible way to select novel killer toxins suitable to be used in biomedical applications. Biotechnology November/December p: 29-30

VAN VUUREN H, JACOBS C (1992) Killer yeasts in the wine industry: a review. Am J Enol Vitic 43: 119-128

VERMUT M, WIDNER W, DINMAN J, WICKNER R (1994) Sequence of MKT1, needed for propagation of M2 satellite dsRNA of the L-A virus of Saccharomyces cerevisiae. Yeast 10: 1477-1479

WICKNER R (1976) Killer of Saccharomyces cerevisiae: a double-stranded ribonucleic acid plasmid. Bacteriol Rev 40: 757-73

YASUYUKI O, WICKNER R (1995) Yeast virus propagation depends critically on free $60 \mathrm{~S}$ ribosomal subunit concentration. Mol Cell Biol 15: 2772-2781

YOUNG T, YAGIU M (1978) A comparison of the killer character in different yeasts and its classification. Antonie van Leeuwenhoek 44: 59-77 